\title{
Approaches for the Elimination of Microbial Contaminants from Lippia multiflora Mold. Leaves Intended for Tea Bagging and Evaluation of Formulation
}

\author{
Doris Kumadoh $\left(\mathbb{D},{ }^{1,2}\right.$ Mary-Ann Archer $\left(\mathbb{D},{ }^{1}\right.$ Michael O. Kyene $\mathbb{D}^{1},{ }^{1}$ Genevieve N. Yeboah, ${ }^{1}$ \\ Ofosua Adi-Dako $\mathbb{D}^{3},{ }^{3}$ Christina Osei-Asare, ${ }^{4}$ Emmanuel Adase $\mathbb{D}^{2},{ }^{2}$ Susana Oteng Mintah, ${ }^{5}$ \\ Hilda Amekyeh (i), ${ }^{6}$ and Alfred A. Appiah ${ }^{7}$
}

${ }^{1}$ Department of Pharmaceutics, Centre for Plant Medicine Research, Mampong-Akuapem, Ghana

${ }^{2}$ Department of Production, Centre for Plant Medicine Research, Mampong-Akuapem, Ghana

${ }^{3}$ Department of Pharmaceutics and Microbiology, School of Pharmacy, University of Ghana, Legon, Accra, Ghana

${ }^{4}$ Department of Pharmaceutics and Microbiology, Central University College, Accra, Ghana

${ }^{5}$ Department of Microbiology, Centre for Plant Medicine Research, Mampong-Akuapem, Ghana

${ }^{6}$ Department of Pharmaceutics, School of Pharmacy, University of Health and Allied Sciences, Ho, Ghana

${ }^{7}$ Department of Phytochemistry, Centre for Plant Medicine Research, Mampong-Akuapem, Ghana

Correspondence should be addressed to Mary-Ann Archer; maryannarcher16@yahoo.com

Received 20 October 2021; Revised 3 February 2022; Accepted 10 February 2022; Published 27 February 2022

Academic Editor: Mounir Tilaoui

Copyright (c) 2022 Doris Kumadoh et al. This is an open access article distributed under the Creative Commons Attribution License, which permits unrestricted use, distribution, and reproduction in any medium, provided the original work is properly cited.

Elimination of microorganisms from herbal products has been a major concern due to its implicated health risk to consumers. Drying of herbal materials has been employed for centuries to reduce the risk of contamination and spoilage. The present study adopted three drying approaches in an attempt to eliminate microorganisms from Lippia multiflora tea bag formulation. This study also evaluated the tea bags and optimized the extraction procedure. The L. multiflora leaves for tea bagging were air-dried and milled (A), oven-dried and milled (B), and microwaved (the milled air-dried leaves) (C). The moisture contents were determined at $105^{\circ} \mathrm{C} \pm 2^{\circ} \mathrm{C}$ for 2 hours to constant weight. Phytochemical parameters such as phytochemical constituents, total water extractive, and $\mathrm{pH}$ were assessed. The microbial safety and quality of the L. multiflora tea bags were evaluated using the British Pharmacopoeia 2019 specifications. The uniformity of the mass of the formulated tea bags was also determined. Extraction from the Lippia tea bags was optimized. The results showed that using the approaches (A, B, and C) adopted for drying and processing, the moisture contents of the formulated tea bags were in the range of $9.75-10.71 \% \mathrm{w} /{ }_{\mathrm{w}}$. All the formulated tea bags contained reducing sugars, phenolic compounds, polyuronides, flavonoids, anthracenosides, alkaloids, saponins, and phytosterols. The $\mathrm{pH}$ range of the formulations was 7.11-7.54, whereas the total water extractive values were in the range of $19.12-20.41 \%$ $\mathrm{w} / \mathrm{w}$. The one-way analysis of variance demonstrated no significant difference in the data obtained from the results from $\mathrm{A}, \mathrm{B}$, and C. The formulation from A was found to be unsafe for consumption due to unacceptable microbial contamination limits. Microbial load of the formulations from B and C were within the BP specifications. All the batches of the formulations passed the uniformity of mass test. An optimized extraction procedure was obtained when one tea bag was extracted in $250 \mathrm{~mL}$ of hot water within the specified time. L. multiflora leaves meant for tea bagging should be oven-dried or microwaved before tea bagging for safe consumption. 


\section{Introduction}

West Africa is endowed with many stouts, woody and aromatic perennial shrubs, of which Lippia multiflora Moldenke is a typical example. L. multiflora belongs to the Verbenaceae family and grows up to a height of 2.8-4 $\mathrm{m} \mathrm{[1].}$ L. multiflora is normally found in the forest savanna, subsavanna, and transitional areas of Ghana. The leaves of L. multiflora have been formulated into a herbal tea that is used because of its aromatic odor and therapeutic property of stress relief $[2,3]$. The leaves of L. multiflora are normally used for the management of mild hypertension and as a diuretic $[4,5]$. Studies on the anti-inflammatory, antimalarial, antioxidant [6], analgesic, and antipyretic activities of the L. multiflora have been conducted justifying its traditional use for the related conditions [4]. The determination of the shelf life of L. multiflora leaves (Lippia tea) indicated a period of 62.97 months as the shelf life in a study conducted by Kumadoh and colleagues when the product was stored at specified temperatures of $30^{\circ} \mathrm{C} \pm 2{ }^{\circ} \mathrm{C} / 70 \% \pm 5 \% \mathrm{RH}$ (relative humidity) [7]. A study on the safety of a powder prepared from the dried leaves of L. multiflora has also been reported by Djengue and colleagues [8]. Results obtained from this study showed that the powder displayed microbial safety at the beginning of storage until at least 18 months of storage without risk of contamination for the consumer. However, powders bought from the markets could not be stored for more than 12 months due to pathogenic and flora contaminations [8].

The presence of microbial contaminants in some herbal products may pose a public health risk to consumers $[9,10]$ with concerns about microbial contamination in herbal products being a major reason why some consumers avoid herbal products in favor of orthodox medicines [11]. When plant material processing strategies such as harvesting, drying, milling, tea bagging, packaging, storage, and distribution are not properly done by following good manufacturing practices, microbial contamination may result $[12,13]$. Some of the ways by which microbial contamination of food products can be eliminated include efficient drying, chilling, curing, and freezing [14]. Irradiation, sterilization, and pasteurization could also make microorganisms inactive for growth and multiplication, thereby preventing contamination. In addition, steam sterilization and ozonation have been reported to be useful in controlling microbial growth in herbs [15]. Studies have shown $L$. multiflora microbial contamination could be reduced by steam treatment [16]. Some factors that should be considered when selecting methods for microbial decontamination include safety, quality, efficacy, practicability, and cost. Care must be taken to prevent the deterioration of essential constituents such as antioxidants and other phytochemical compounds in plant materials during the microbial decontamination process [16]. Microorganisms contaminate various parts of herbal plants, including leaves, stems, flowers, seeds, and roots $[17,18]$. It is important to eliminate microbial contaminants in the herbal tea of L. multiflora in order to ensure its safety and quality. The aim of this study is to develop a simple and practical method for the elimination of microbial contaminants from herbal tea without adversely affecting the phytochemical constituents and quality properties of the tea. An attempt has also been made to do an optimization of the extraction process for the formulated tea bags.

\section{Materials and Methods}

2.1. Plant Material Collection. Fresh leaves of L. multiflora were harvested from the Centre for Plant Medicine Research (CPMR) farm at Mampong-Akuapem, Ghana ( $5^{\circ} 55^{\prime} 06.6^{\prime \prime}$ $\mathrm{N}, 0^{\circ} 07^{\prime} 57^{\prime} 57 \mathrm{~W}$ ) and authenticated by the Plant Development Department, CPMR. The plant specimen has been placed in its herbarium with the identification code CPMR 5073. The methods that were used for processing the materials before tea bagging have been detailed below.

2.2. Plant Material Processing. Three different methods were used for the processing of the plant material. For each method, four different batches of tea bags were formulated for subsequent analyses. The tea bags manufactured were batch coded as LTB1, LTB2, LTB3, and LTB4, respectively.

2.2.1. Methods of Processing: Air-Drying, Oven-Drying, and Microwaving of L. multiflora Mold. Leaves. The method of processing the fresh leaves of $L$. multiflora was modified from Mahanom et al [19], Roshanak et al. [20], and Manzano Santana et al. [21]. The fresh leaves of L. multiflora were washed in $70 \%(\mathrm{v} / \mathrm{v})$ ethanol and subsequently washed with water to remove all residual ethanol, dust, and unwanted materials accumulated on the leaves. The leaves were airdried for 7 days on wooden-structured shelves with their bottoms covered with a wire mesh in a well-ventilated drying room for the air-drying method. In the oven-drying method, the leaves, after being washed, were dried in an oven (IGNIS, Italy) at a temperature of $70^{\circ} \mathrm{C}$ for 2 hours. Dried leaves obtained using the two methods were then milled to obtain a coarse powder (ca $2 \mathrm{~mm}^{2}$ in size) using a stainless-steel hammer mill (JICA, Japan) machine and sieved using a $2 \mathrm{~mm}$ mesh sieve. The third method of processing involved microwaving of a sample of the milled plant material obtained from the air-drying method for 5 minutes. Tea bagging of the material was done using a tea-bagging machine (GATBPM, India). The obtained tea bags were packaged in ziplock bags and placed in a box. The procedure was repeated for four different batches of the product for each processing method.

2.3. Determination of Moisture Content of Powder for Tea Bagging. The moisture contents (percentage) of $3 \mathrm{~g}$ of milled material obtained from each processing method which were to be used in the preparation of the tea bags were determined using a moisture content analyzer (Kern, MLB 50-3, Germany) at a temperature of $105^{\circ} \mathrm{C} \pm 2{ }^{\circ} \mathrm{C}$ for $2 \mathrm{~h}$ to constant weight. The moisture content was deduced as the percentage of the lost weight divided by the initial weight. This was 
determined in triplicate for each method and the mean percentage moisture content calculated [22].

2.4. Phytochemical Analysis. The formulated tea bags were assessed for phytochemical parameters such as phytochemical constituents, total water extractive, and $\mathrm{pH}$. Standard phytochemical screening tests were used to detect secondary metabolites from L. multiflora. Mayer's tests for alkaloids, Fehling's test for free reducing sugars, the Liebermann-Burchard test for phytosterol and triterpenes, froth test for saponins, Shinoda's test for flavonoids, Borntrager's test for free anthracenosides, and ferric chloride solution test for phenolics were used [23].

2.5. Determination of $p H$. A $\mathrm{pH}$ meter was calibrated with standard $\mathrm{pH}$ buffer solutions beginning with buffers of $\mathrm{pH} 7$ and 10 (Riedel-de Haen, Germany) followed by that with $\mathrm{pH}$ 4 (Reagacon, Ireland) to determine the linearity of response of the electrode. To determine the $\mathrm{pH}$, a cup was filled with a portion of a $1 \% \mathrm{w} / \mathrm{v}$ infusion prepared from the tea bags to obtain a preliminary value. Subsequent readings were taken on additional portions of the same sample to yield more constant $\mathrm{pH}$ values that were reproducible to \pm 0.04 units and that showed drifts of less than \pm 0.04 unit in $2 \mathrm{~min}$, and the maximum $\mathrm{pH}$ value obtained recorded. The procedure was done in triplicate for all four batches of products from the three processing methods [24].

2.6. Determination of Total Water Extractive. One gram of the material in a Lippia tea bag was weighed into a $250 \mathrm{~mL}$ flask with a stopper. Next, $100 \mathrm{~mL}$ of distilled water was added and the mixture was placed on a water bath for 1 hour. The extract was filtered using Johnson test paper (Qualitative filter paper, grade $304 ; 125 \mathrm{~mm}$ ) and $10 \mathrm{~mL}$ of the filtrate was pipetted for drying in an evaporating dish at $105^{\circ} \mathrm{C}$ for $1 \mathrm{~h}$ to a constant weight. The evaporating dish containing the residue was transferred into a desiccator to cool and later weighed [25].

The weight of the residue was calculated as follows: Weight of residue $=($ weight of dish + residue $)-($ weight of empty dish).

The total water extractive value was calculated as follows: percentage weight per weight

$$
\left(\% \frac{w}{w}\right)=\frac{\text { weight of residue }}{\text { initial weight in } 10 \mathrm{~mL}} \times 100 .
$$

2.7. Microbial Load Test Using Total Bacterial, Fungal, and Pathogenic Bacterial Counts. The microbial safety and quality of the L. multiflora tea bags were assessed using the British Pharmacopoeia 2019 specifications. The tests were used to quantify the number of bacteria and fungi isolated that are able to grow aerobically in $1 \mathrm{~g}$ of sample. All microbial analyses were carried out in triplicate. Viability was assessed by the pour plate method using plate count agar for bacterial counts and malt extract agar for fungi identification.

The media were prepared according to the manufacturer's instructions and incubated at $37^{\circ} \mathrm{C}$ for $24 \mathrm{~h}$ for bacterial screening and at $25^{\circ} \mathrm{C}$ for 5 days for fungal screening. At the end of the incubation period, the number of colony-forming units per gram (CFU/g) was calculated by multiplying the average number of colonies by the dilution factor. All microbial analyses were carried out in triplicate. For investigating the presence of pathogenic bacteria, selective media used for the identification of Escherichia coli, Staphylococcus spp., and Salmonella spp. were MacConkey agar, mannitol salt agar, and xylose lysine deoxycholate agar, respectively.

2.8. Mass Uniformity of the Formulated Tea Bags. The average mass of 20 randomly selected units of the tea bags was determined by weighing a single filled tea bag, opening it whilst making sure no fragments were lost with complete emptying. The weight of the empty bag was noted and the weight of the content was calculated by deduction. The procedure was repeated on the 19 remaining tea bags. The uniformity of mass was then determined. This procedure was done in triplicate for all four batches of products obtained from the three different processing methods [22].

2.9. Extraction Method Optimization. The method for optimization of the extraction was modified from Chandini et al. [26] and Yuto et al. [27]. One tea bag ( $2 \mathrm{~g}$ net weight) was soaked in $300 \mathrm{~mL}$ of hot water (freshly boiled), allowed to extract for about 10 minutes, and filtered. The volume of the filtrate was recorded and the total solid residue was determined. The total extract available in the filtrate was then calculated. The procedure was repeated using various volumes of the hot water $(250,200$, and $150 \mathrm{~mL}$ ) for the extraction procedure. The procedure was done in triplicate for each extraction volume. The same procedure above was also repeated using two tea bags (4 $\mathrm{g}$ net weight).

2.10. Statistical Analyses. The standard deviations and means of the replicate determinations were analyzed using Microsoft excel, 2016 version. The one-way analysis of variance (ANOVA) was used to analyze the $\mathrm{pH}$, moisture content, and total water extractive data obtained from using the three different processing methods. GraphPad Prism version 7 was used to prepare all the plots. In the optimization of extraction study, linear regression analyses were employed.

\section{Results and Discussion}

3.1. Physicochemical Properties and Phytoconstituents Present in the Formulated Tea Bags. The results from the analyses of the four different batches of tea bags obtained using the three processing methods as presented in Table 1 showed that all samples produced by the three processing methods contained phytochemical constituents such as reducing sugars, 
TABle 1: Phytochemical properties of the formulated tea bags.

\begin{tabular}{|c|c|c|c|c|c|c|c|c|c|c|c|c|c|}
\hline \multirow{3}{*}{ Phytochemical test } & \multirow{3}{*}{ Inference } & \multicolumn{12}{|c|}{ Processing approach } \\
\hline & & \multicolumn{4}{|c|}{ A } & \multicolumn{4}{|c|}{$\mathrm{B}$} & \multicolumn{4}{|c|}{$\mathrm{C}$} \\
\hline & & LTBI & LTB2 & LTB3 & LTB4 & LTBI & LTB2 & LTB3 & LTB4 & LTBI & LTB2 & LTB3 & LTB4 \\
\hline Reducing sugar & Brick-red colouration & + & + & + & + & + & + & + & + & + & + & + & + \\
\hline Saponins & $\begin{array}{l}\text { Formation of froth which } \\
\text { persists for } 10 \mathrm{~min}\end{array}$ & + & + & + & + & + & + & + & + & + & + & + & + \\
\hline $\begin{array}{l}\text { Phenolic } \\
\text { compounds }\end{array}$ & Dark green colouration & + & + & + & + & + & + & + & + & + & + & + & + \\
\hline Polyuronides & Violet precipitation & + & + & + & + & + & + & + & + & + & + & + & + \\
\hline Flavonoids & Orange colouration & + & + & + & + & + & + & + & + & + & + & + & + \\
\hline Anthracenosides & Red colouration & + & + & + & + & + & + & + & + & + & + & + & + \\
\hline Alkaloids & Cream precipitation & + & + & + & + & + & + & + & + & + & + & + & + \\
\hline Phytosterols & Dark green colouration & + & + & + & + & + & + & + & + & + & + & + & + \\
\hline
\end{tabular}

Approach A: air-drying of the fresh leaves of L. multiflora Mold. before tea bagging; Approach B: oven-drying of the fresh leaves of $L$. multiflora Mold. before tea bagging; Approach C: Microwaving of air-dried processed sample of L. multiflora Mold. before tea bagging. + means present.

phenolic compounds, flavonoids, alkaloids, saponins, polyuronides, anthracenosides, and phytosterols. The presence of these phytochemicals has been reported $[1,28]$ where the parameters were not affected by the drying methods used. A similar study was conducted by Manzano Santana et al. [21] where the drying methods used on Ilex guayusa leaves did not affect the phytochemical constituents present in the plant. It did, however, increase the concentration of secondary metabolites in the aqueous and ethanol extracts tested. Only alkaloids were found in the leaves of L. multiflora collected from six districts in Benin, according to Djengue et al. [29]. The current study validates the previous studies reported. The occurrence of these essential phytochemical constituents in L. multiflora may be contributed to the antifungal, antibacterial, antiedema, antiinflammatory, antiviral, antimalarial, and anti-stress activities of the plant [28-33]. The results obtained indicate the oven temperature of $70^{\circ} \mathrm{C}$ did not affect the presence of the phytochemical constituents determined in the samples. The reduction in the amounts of volatile compounds in plant materials during oven-drying depends on the volatility and chemical structure of the constituents [34]. Radünz et al. [35] observed no significant difference in the essential oil content of fresh leaves of $L$. sidoides compared to the leaves that were oven-dried at temperatures of $40^{\circ} \mathrm{C}$ to $70^{\circ} \mathrm{C}$. Meanwhile, the essential oil content of the sample dried in ambient air was $8 \%$ lower. When this evaluation was repeated, similar results were obtained with no significant qualitative changes in essential oils (thymol) comparable to the fresh plant [36]. $L$. aliba leaves were examined under six different drying treatments, using air at ambient temperature and air heated up to $80^{\circ} \mathrm{C}$. The investigators concluded that drying of the plant for marketing purposes can be carried out using air that is heated to $40-80^{\circ} \mathrm{C}$ [37]. However, the changes in the chemical composition of essential oils and compounds present in herbal tea/products depend on individual medicinal plants, the drying temperature conditions, and the drying time [38, 39].

The one-way ANOVA results for the total water extractives (means, standard deviation (SD) of the four different batches) after using the three different processing methods showed no significant difference $(P>0.05)$ in the means of the extractive values obtained, as has been indicated in Figure 1. This indicates that the different processing techniques did not affect the total water extractives. According to a study on the determination of total water extractives of poly-herbal formulations, the water-soluble extractives of the tested materials ranged from 8.23 to $34.52 \%$ [40]. From the results obtained as indicated in Figure 1, the total water extractive obtained was in the range of 19.53 to $20.93 \%$, which indicates a good extraction for all three drying methods. A lower total extractive value may indicate an exhausted material, contamination, improper drying, storage, or preparation, whereas a higher total extractive value may also indicate the presence of more watersoluble contents in the plant material [40].

The results (Figure 2) illustrated that the $\mathrm{pH}$ range of the products was 3.00 to 5.09. Statistical analysis of this result using the one-way ANOVA method of the samples prepared showed no significant difference $(P>0.05)$ in the $\mathrm{pH}$ values recorded for the different batches prepared via the different processing methods. This indicates that the processing methods did not affect the $\mathrm{pH}$ of the products. In a previous reported research project [41], the $\mathrm{pH}$ of some herbal medicines was determined to ascertain their acidity or alkalinity. Additionally, Onwordi et al. [42] have reported a $\mathrm{pH}$ range of 3.35-8.00 for some liquid herbal medicines sold in Nigeria, whereas an acidic $\mathrm{pH}$ range of 1.05-3.55 has also been reported for liquid herbal medicinal products [43]. Meanwhile, the obtained $\mathrm{pH}$ falls within the reported tolerable $\mathrm{pH}$ for natural plants, i.e., 4.0-7.5 [44]. Generally, the buffer systems of the body neutralize the accumulated acids and when this system is burdened, alkaline minerals from bones and vital organs are used by the body to neutralize acidic compounds. This results in the deterioration of the bones and the organs, leading to osteoporosis and undesirable effects on the immune, circulatory, digestive, respiratory, and other body systems [45]. The ingestion of herbal medicines with high acidic $\mathrm{pH}$ reduces the $\mathrm{pH}$ of the fluids in the stomach above the acceptable level required for metabolism, thus hindering enzyme action [45]. Enzymes are sensitive to $\mathrm{pH}$ changes and are known to function best at a 


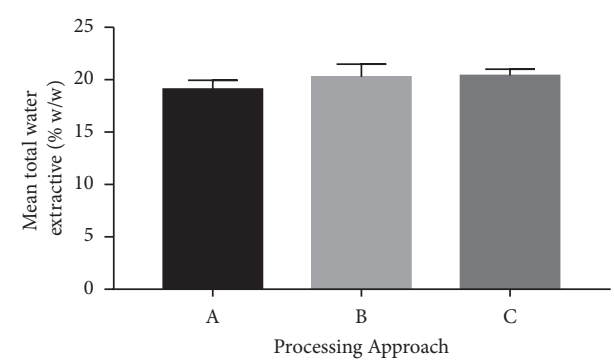

Figure 1: Graph of mean total water extractive from the various processing approaches of the formulated tea bags. Approach A: airdrying of the fresh leaves of $L$. multiflora Mold. before tea bagging; Approach B: oven-drying of the fresh leaves of L. multiflora Mold. before tea bagging; Approach C: microwaving of air-dried processed sample of L. multiflora Mold. before tea bagging. Values are mean $\pm S D$.

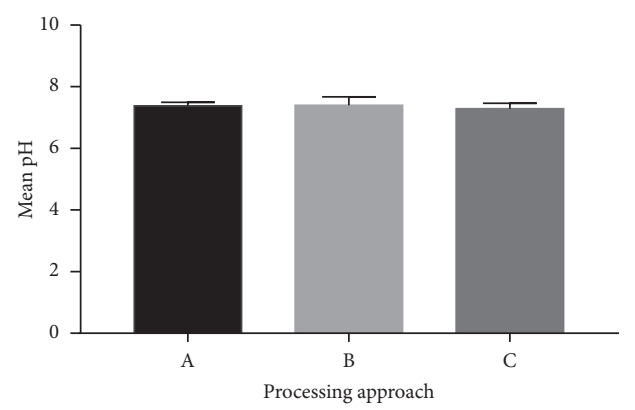

Figure 2: Graph of mean $\mathrm{pH}$ values obtained. Approach A: airdrying of the fresh leaves of $L$. multiflora Mold. before tea bagging; Approach B: oven-drying of the fresh leaves of L. multiflora Mold. before tea bagging; Approach C: microwaving of air-dried processed sample of L. multiflora Mold. before tea bagging. Values are mean $\pm S D$.

specific $\mathrm{pH}$ range [45]. However, the $\mathrm{pH}$ values obtained for the Lippia tea bags from the three processing methods (A, B, and C) in this study ranged from 7.11 to 7.54 , which is within the acceptable range of 4.0-7.5 reported by Edebi and Gideon [44]. This indicates that the teas produced from the various processing methods may be safe for consumption with regard to their $\mathrm{pH}$.

The moisture content of the air-dried sample (A) was the highest, with an average value of $10.71 \%$, followed by that of the oven-dried sample (B, 9.83\%). The microwave-dried sample (C) had a moisture content of $9.75 \%$. Nonetheless, statistical analysis using one-way ANOVA demonstrated no significant $\left(\mathrm{P}^{<} 0.01\right)$ difference between the recorded values for A compared to B and C as shown in Figure 3. This indicates that the processing methods affected the moisture contents of the products. A higher moisture content as seen in the air-dried sample may lead to increased susceptibility to microbial growth. Moisture content can be understood as the amount of water contained in a material or substance. The moisture content of a herbal plant helps to estimate the total solid matter and it is one of the major factors responsible for the deterioration of solid, powdered herbal drugs and formulations. A relatively lower moisture content is always desirable for higher drug stability and the

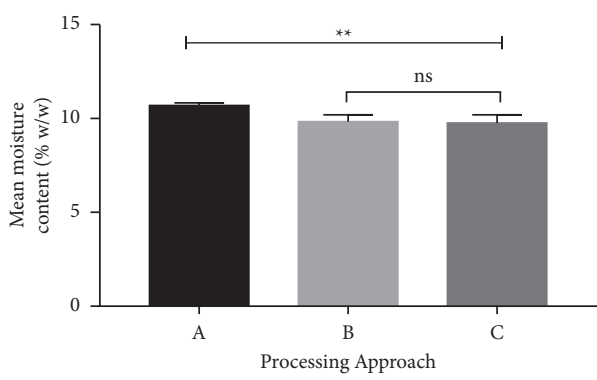

FIGURE 3: Graph of the mean moisture content. Approach A: airdrying of the fresh leaves of L. multiflora Mold. before tea bagging; Approach B: oven-drying of the fresh leaves of L. multiflora Mold. before tea bagging; Approach C: microwaving of air-dried processed sample of L. multiflora Mold. before tea bagging. Values are mean \pm SD. $P>0.05$ not significant (ns), $P<0.01$ significant $\left(^{* *}\right)$.

prevention of fungal and bacterial growth. Eko et al. [46] in a moisture content determination study reported a low moisture content of $8.6 \%$ for the flowers, roots, leaves, fruits, and bark of medicinal plants that had been oven-dried, while the moisture content of air-dried samples was $9.81 \%$. Ahmad et al. [47] have also reported moisture contents of $11.0 \%$ and $12.14 \%$ for field-grown leaves and roots, respectively, of Rauvolfia serpentia at $105^{\circ} \mathrm{C}$. The moisture content of herbal plants depends on the nature and type of herb, postharvest practices, the age of the plants, and the chemical composition of the plant. The moisture contents of L. multiflora leaf, flower, and market powders, as evaluated by Djengue and his team [8], were found to be $7.42 \%, 9.89 \%$, and $11.67 \%$, respectively. The results of the present study showed that the moisture content of the L. multiflora leaves was in the range of $9.75-10.71 \%$, which is consistent with the reported results [8].

3.2. Uniformity of Mass of the Formulated Tea Bags. For the uniformity of mass, the acceptance criteria for weights between $1.5 \mathrm{~g}$ and $2 \mathrm{~g}$ is that not more than two sachets should deviate by more than $10 \%$ from the average mass and none should deviate by more than $20 \%$ [22]. As can be observed from Table 2 the batches passed the uniformity of mass test. It can be inferred that the tea-bagging machine helped ensure the uniform filling of tea bags. In addition, it helps to provide a product that is convenient for patient usage compared to powders that have not been bagged.

3.3. Microbial Load of L. multiflora Mold. Tea Bags. Results of the microbial load analyses of the air-dried L. multiflora Mold. tea bags have been presented in Table 3. It can be observed that all the four batches of the products failed the microbial load test. The quality and safety of herbal teas for commercial use can be promoted if microbial contamination levels are addressed through appropriate quality control processes during the preparation of the plant material for tea bagging. Though some consumers believe that hot water steeping of herbal teas could reduce microbial contamination, once there is a high level of contamination beyond acceptable limits, steeping of herbal tea in hot or 
TABLE 2: Uniformity of mass of the formulated tea bags.

\begin{tabular}{|c|c|c|c|}
\hline $\begin{array}{l}\text { Processing } \\
\text { approach }\end{array}$ & $\begin{array}{l}\text { Batch of } \\
\text { product }\end{array}$ & $\begin{array}{c}\text { Number of tea bags deviating by more than } 10 \% \\
\text { from mean }(N=20)\end{array}$ & $\begin{array}{c}\text { Number of tea bags deviating by more than } 20 \% \\
\text { from mean }(N=20)\end{array}$ \\
\hline \multirow{4}{*}{ A } & LTB1 & 2 & 0 \\
\hline & LTB2 & 1 & 0 \\
\hline & LTB3 & 2 & 0 \\
\hline & LTB4 & 2 & 0 \\
\hline \multirow{4}{*}{ B } & LTB1 & 1 & 0 \\
\hline & LTB2 & 2 & 0 \\
\hline & LTB3 & 1 & 0 \\
\hline & LTB4 & 1 & 0 \\
\hline \multirow{4}{*}{ C } & LTB1 & 1 & 0 \\
\hline & LTB2 & 0 & 0 \\
\hline & LTB3 & 1 & 0 \\
\hline & LTB4 & 2 & 0 \\
\hline
\end{tabular}

Approach A: air-drying of the fresh leaves of L. multiflora Mold. before tea bagging; Approach B: oven-drying of the fresh leaves of L. multiflora Mold. before tea bagging; Approach C: microwaving of air-dried processed sample of L. multiflora Mold. before tea bagging.

TABle 3: Microbial load analyses of tea bags prepared from the air-dried leaves of L. multiflora Mold.

\begin{tabular}{lccccc}
\hline Test conducted & LTB1 $(\mathrm{cfu} / \mathrm{g})$ & LTB2 $(\mathrm{cfu} / \mathrm{g})$ & LTB3 $(\mathrm{cfu} / \mathrm{g})$ & LTB4 $(\mathrm{cfu} / \mathrm{g})$ & Acceptance criterion $(\mathrm{BP}, 2019)$ \\
\hline${ }^{1} \mathrm{TAMC} / 37^{\circ} \mathrm{C} / 24$ hours/PCA & $8.6 \times 10^{8}$ & TNTC & TNTC & $7.3 \times 10^{9}$ & $\leq 5.0 \times 10^{7}$ \\
${ }^{2} \mathrm{TYMC} / 25{ }^{\circ} \mathrm{C} / 5$ days/MEA & $4.9 \times 10^{7}$ & TNTC & TNTC & $5.1 \times 10^{6}$ & $\leq 5.0 \times 10^{5}$ \\
Escherichia coli (E. coli) & + & - & + & - & Absence \\
Salmonella spp. & - & - & - & - & Absence \\
Staphylococcus spp. & - & + & - & Absence \\
\hline
\end{tabular}

BP, British Pharmacopoeia; ${ }^{1}$ TAMC: total aerobic microbial counts, ${ }^{2}$ TYMC: total yeast and mold counts; TNTC: too numerous to count; -: absent; +: present; PCA: plate count agar; MEA: malt extract agar.

boiling water alone may not be able to clear the contamination to acceptable levels [48]. Drying plays a pivotal role in good manufacturing practices during the production of herbal products, as it helps reduce the moisture content of materials, thus preventing microbial contamination and prolonging the shelf life of the materials [49]. The presence of aerobic bacteria and fungi beyond acceptable limits may be due to frequent multiplication in the air under ambient temperature conditions and microbial contaminants settling on leaves during the drying process [50]. E. coli was present in the LTB1 and LTB3 samples. The presence of E. coli and Staphylococcus spp. has been reported in some homemade and commercial herbal medicine [51] as well as in some dried herbs and teas [52]. E. coli may cause urinary tract infections, pneumonia, and diarrhea [53]. Contamination from Staphylococcus spp. could also cause cellulitis, stomachache, scalded-skin syndrome, and impetigo [54]. The relatively higher moisture content of the air-dried powders (Figure 3) possibly resulted in the failing of the microbial load test. The high moisture content made the samples more susceptible to microbial contamination in addition to contamination from the environment during the air-drying process. A study by Djengue et al. [8] showed that high moisture and ash contents in the powders of L. multiflora favor the growth and development of yeast and molds. The load detection for Salmonella spp. in this study was within the acceptable criteria. Similar results have also been reported by Djengue and his team [8], who found the coliform detection threshold for Salmonella spp. in dried L. multiflora leaves to be below the acceptable limits.
From Table 4, it can be observed that the total aerobic bacteria, yeast, and mold counts in all the four batches of oven-dried L. multiflora Mold. leaves before tea bagging were within the acceptable specification limits, which could be due to the drying conditions employed. Kulshrestha et al. [55] have reported that drying herbs at a relatively high temperature decreases the total microbial counts. Research has also revealed that L. multiflora leaves contain some essential oils that have antimicrobial properties [13]. It has been revealed in some studies that essential oils in the leaves of plants have a strong inhibitory effect on the growth of Staphylococcus aureus and Enterococcus hirae and a moderate inhibitory effect on Candida albicans and Saccharomyces cerevisiae [30, 56, 57]. Specially, essential oils such as carvacrol and thymol have been shown to have antimicrobial properties in previous studies [32, 58, 59]. This may account for the low microbial contamination observed in L. multiflora tea bag samples investigated using oven-dried and microwave-dried methods. Meanwhile, high microbial contamination was observed in the air-dried samples.

It can be observed from Table 5 that tea bags produced from the microwaved air-dried samples passed the microbial load tests. In comparison to the air-dried sample, which failed the tests, it can be deduced that microwaving of the samples may have caused deactivation of the microbial agents present in the air-dried sample. Microwaves use nonionizing electromagnetic waves of $1 \mathrm{~m}$ to $1 \mathrm{~mm}$ and frequencies between 0.3 and $300 \mathrm{GHz}$ [60]. The application of microwave treatment on spices and herb samples has 
TABle 4: Microbial load analyses of tea bags prepared from the oven-dried leaves of L. multiflora Mold.

\begin{tabular}{lccccc}
\hline Test conducted & LTB1 $(\mathrm{cfu} / \mathrm{g})$ & LTB2 $(\mathrm{cfu} / \mathrm{g})$ & LTB3 $(\mathrm{cfu} / \mathrm{g})$ & LTB4 $(\mathrm{cfu} / \mathrm{g})$ & Acceptance criterion $(\mathrm{BP}, 2019)$ \\
\hline${ }^{1} \mathrm{TAMC} / 37^{\circ} \mathrm{C} / 24 \mathrm{~h} / \mathrm{PCA}$ & $1.2 \times 10^{3}$ & $1.1 \times 10^{3}$ & $1.8 \times 10^{2}$ & $2.5 \times 10^{4}$ & $\leq 5.0 \times 10^{7}$ \\
${ }^{2} \mathrm{TYMC} / 25^{\circ} \mathrm{C} / 5$ days/MEA & $6.0 \times 10^{2}$ & $5.5 \times 10^{2}$ & $3.9 \times 10^{3}$ & $7.4 \times 10^{4}$ & $\leq 5.0 \times 10^{5}$ \\
E. coli & - & - & - & - & Absence \\
Salmonella spp. & - & - & - & - & Absence \\
Staphylococcus spp. & - & - & - & Absence \\
\hline
\end{tabular}

BP, British Pharmacopoeia; ${ }^{1}$ TAMC: total aerobic microbial counts; ${ }^{2}$ TYMC: total yeast and mold counts; -: absent; +: present; PCA: plate count agar; MEA: malt extract agar.

TABle 5: Microbial load analyses of tea bags prepared from the microwaved air-dried leaves of L. multiflora Mold.

\begin{tabular}{lccccc}
\hline Test conducted & LTB1 $(\mathrm{cfu} / \mathrm{g})$ & LTB2 $(\mathrm{cfu} / \mathrm{g})$ & LTB3 $(\mathrm{cfu} / \mathrm{g})$ & LTB4 $(\mathrm{cfu} / \mathrm{g})$ & Acceptance criterion $(\mathrm{BP}, 2019)$ \\
\hline${ }^{1} \mathrm{TAMC} / 37^{\circ} \mathrm{C} / 24 \mathrm{~h} / \mathrm{PCA}$ & $8.7 \times 10^{4}$ & $1.3 \times 10^{3}$ & $2.6 \times 10^{4}$ & $6.9 \times 10^{5}$ & $\leq 5.0 \times 10^{7}$ \\
${ }^{2} \mathrm{TYMC} / 25^{\circ} \mathrm{C} / 5$ days/MEA & $6.5 \times 10^{3}$ & $9.1 \times 10^{4}$ & $4.3 \times 10^{3}$ & $3.8 \times 10^{3}$ & $\leq 5.0 \times 10^{5}$ \\
E. coli & - & - & - & - & Absence \\
Salmonella spp. & - & - & - & - & Absence \\
Staphylococcus spp. & - & - & - & Absence \\
\hline
\end{tabular}

BP, British Pharmacopoeia; ${ }^{1}$ TAMC: total aerobic microbial counts; ${ }^{2}$ TYMC: total yeast and molds counts; -: absent; +: present; PCA: plate count agar; MEA: malt extract agar.

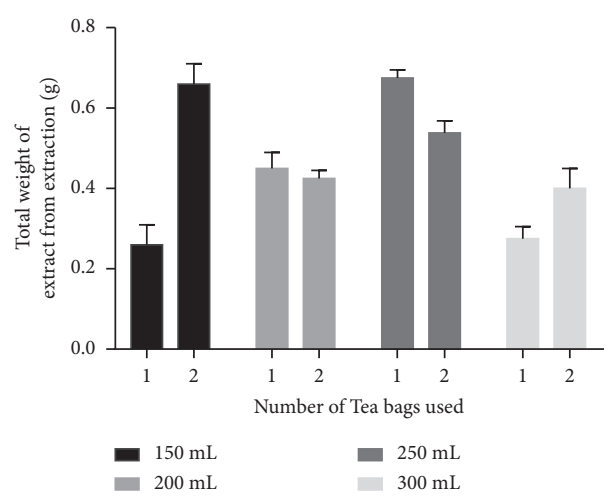

FIGURE 4: Weight of extracts obtained from the tea bags in the extraction procedure. "1" indicates one tea bag (2 g) and " 2 " indicates two tea bags (4).

TABle 6: Results of optimization of extraction from Lippia tea bags.

\begin{tabular}{|c|c|c|c|c|}
\hline $\begin{array}{l}\text { Weight of tea bags used in } \\
\text { extraction }(\mathrm{g})\end{array}$ & $\begin{array}{l}\text { Volume of water used in } \\
\text { extraction }(\mathrm{mL})\end{array}$ & $\begin{array}{l}\text { Volume of filtrate obtained } \\
\qquad(\mathrm{mL}) \\
N=3\end{array}$ & $\begin{array}{l}\text { Total solid residue } \\
\qquad \begin{array}{c}\% \mathrm{w} / \mathrm{v}) \\
N=3\end{array} \\
\end{array}$ & $\begin{array}{l}\text { Total extract } \\
\text { in } \\
\text { filtrate }(\mathrm{g})\end{array}$ \\
\hline 2 & 300 & $265 \pm 5$ & $0.15 \pm 0.02$ & $0.400 \pm 0.05$ \\
\hline 2 & 250 & $215 \pm 2$ & $0.25 \pm 0.01$ & $0.538 \pm 0.02$ \\
\hline 2 & 200 & $170 \pm 5$ & $0.25 \pm 0.02$ & $0.425 \pm 0.03$ \\
\hline 2 & 150 & $130 \pm 2$ & $0.20 \pm 0.04$ & $0.26 \pm 0.05$ \\
\hline 4 & 300 & $275 \pm 4$ & $0.10 \pm 0.01$ & $0.275 \pm 0.03$ \\
\hline 4 & 250 & $225 \pm 3$ & $0.30 \pm 0.01$ & $0.675 \pm 0.02$ \\
\hline 4 & 200 & $180 \pm 5$ & $0.25 \pm 0.02$ & $0.450 \pm 0.04$ \\
\hline 4 & 150 & $120 \pm 2$ & $0.55 \pm 0.04$ & $0.660 \pm 0.05$ \\
\hline
\end{tabular}

been studied by Dababneh [61], who found that exposure of dry and wet spices and herbs to microwaves reduced microbial populations in the samples. The study concluded that decontamination of materials at home and in industries can be done by microwaving. The use of microwave radiation to reduce microbial contamination is applied in the pharmaceutical and food industries for drying, decontamination, defrosting, and inactivation of enzymes [62-66]. In addition, microwaving reduces the number of pathogenic and nonpathogenic bacteria in samples [67]. Research showed that microwave treatment reduced total bacteria coliforms and a yeast population (Brettanomyces bruxellensis) in oak wine barrels, as well as minimizing preservative use [68]. A study by Slobodan et al. [69] also 
revealed that microwave radiation can have substantial effects on the growth of microbial cultures. Additionally, the tendency to kill microorganisms depends on factors such as the frequency of the microwave and the tendency of microorganisms to absorb the microwave energy. However, highenergy and high-frequency microwaves prevent the growth of microorganisms. Thermal and nonthermal effects occur due to the radiation released from microwaving, which destroys the structure of the microorganisms [70]. In previous studies, the occurrence of thermal effects led to the absorption of radiation, which caused agitation of the molecules inside the bacterial cells to produce heat, thereby forming a mass in the cytoplasm due to protein denaturation $[15,70]$. Nonthermal effects of microwaves, on the other hand, cause changes in the cell anatomy and proteins of microorganisms [70, 71]. Moreover, microwaving was reported to reduce Salmonella in peanut butter [72], and it was also used in drying plant-made products [73]. Microwaving also facilitates the extraction of biochemical compounds from plants via the drying process $[74,75]$. Specifically, the process has been used in the isolation of essential oils and antioxidants within a short time from ethno-medicinal plants [76].

3.4. Optimization of Extraction of Lippia tea Bags. It can be seen from Figure 4 and Table 6 that extraction was optimized with one tea bag in $250 \mathrm{~mL}$ of hot water for 10 minutes.

\section{Conclusion}

The approaches of oven-drying and microwaving of airdried samples that were adopted to eliminate microbial contamination from tea bags prepared from L. multiflora leaves were successful. The moisture contents of these samples were relatively lower and the physiochemical properties were found to be within acceptable limits. The phytochemical constituents observed in the L. multiflora leaves were not affected by the applied methods. The oven and microwave drying methods caused a decrease in the level of microbial contamination in L. multiflora leaves to acceptable limits relative to the air-dried samples, making them safer for consumption relative to the air-dried sample. The optimized extraction procedure can be used to achieve an effective extraction using a minimal number of tea bags.

\section{Data Availability}

The data used to support the findings of this study are available from the corresponding author upon request.

\section{Conflicts of Interest}

The authors have no potential conflicts of interest.

\section{References}

[1] M. E. Pascual, K. Slowing, E. Carretero, D. Sánchez Mata, and A. Villar, "Lippia: traditional uses, chemistry and pharmacology: a review," Journal of Ethnopharmacology, vol. 76, no. 3, pp. 201-214, 2001.
[2] F. Avlessi, G. Alitonou, D. K. Sohounhloue, C. Menut, and J. M. Bessiere, "Aromatic plants of tropical west Africa. Part XIV. Chemical and biological investigation ofLippia multifloraMold. Essential oil from benina," Journal of Essential Oil Research, vol. 17, no. 4, pp. 405-407, 2005.

[3] H. R. Juliani, M. Wang, H. Moharram et al., "Intraspecific variation in quality control parameters, polyphenol profile, and antioxidant activity in wild populations of Lippia multiflora from Ghana," ACS Symposium Series, vol. 925, pp. 126-142, 2006.

[4] A.-W. Etou-Ossibi, J. Nzonzi, J. V. Mombouli, G. E. NsondéNtandou, J.-M. Ouamba, and A. A. Abena, "Screening chimique et effets de l'extrait aqueux du Lippia multiflora Moldenke sur le cœur isolé du crapaud," Phytothérapie, vol. 3, no. 5, pp. 193-199, 2005.

[5] A. C. Ekissi, A. G. Konan, A. Yao-Kouame, B. Bonfoh, and S. Kati-Coulibaly, "Sensory evaluation of green tea from Lippia multiflora Moldenke leaves," European Scientific Journal, vol. 10, no. 3, pp. 536-545, 2014.

[6] de C. S. L. Miranda, M. A. T. Fujishima, L. Bruno de Paula, P. C. Mastroianni, F. Fábio Oliveira de Sousa, and J. Oliveira da Silva, "Microbial contamination in herbal medicines: a serious health hazard to elderly consumers," BMC Complementary Medicine and Therapies, vol. 20, p. 17, 2020.

[7] D. Kumadoh, K. O. Kwakye, N. Kuntworbe, O. Adi-Dako, and J. A. Appenahier, "Determination of shelf life of four herbal medicinal products using high-performance liquid chromatography analyses of markers and the Systat Sigmaplot software," Journal of Applied Pharmaceutical Science, vol. 10, no. 6, pp. 072-080, 2020.

[8] H. W. Djengue, A. Adjatin, G. Agbankpé et al., "Physicochemical and microbiological characterizations of the leaf and flower powder of Lippia multiflora moldenk, a leaf vegetable consumed in Benin," Asian Journal of Biology, vol. 9, no. 3, pp. 41-50, 2020.

[9] E. R. Nestmann, M. Harwood, and S. Martyres, “An innovative model for regulating supplement products: natural health products in Canada," Toxicology, vol. 221, no. 1, pp. 50-58, 2006.

[10] M. Bianco, C. Luquez, L. Dejong, and R. Fernandez, "Presence of Clostridium botulinum spores in Matricaria chamomilla (chamomile) and its relationship with infant botulism," International Journal of Food Microbiology, vol. 121, no. 3, pp. 357-360, 2008.

[11] R. A. Street, W. A. Stirk, and J. Van Staden, "South African traditional medicinal plant trade-Challenges in regulating quality, safety and efficacy," Journal of Ethnopharmacology, vol. 119, no. 3, pp. 705-710, 2008.

[12] H. M. Martins, M. L. Martins, M. I. Dias, and F. Bernardo, "Evaluation of microbiological quality of medicinal plants used in natural infusions," International Journal of Food Microbiology, vol. 68, no. 1-2, pp. 149-153, 2001.

[13] I. Kosalec, J. Cvek, and S. Tomić, "Contaminants of medicinal herbs and herbal products," Archives of Industrial Hygiene and Toxicology, vol. 60, no. 4, pp. 485-501, 2009.

[14] G. W. Gould, "Methods for preservation and extension of shelf life," International Journal of Food Microbiology, vol. 33, no. 1, pp. 51-64, 1996.

[15] S.-Y. Kim, E.-K. Jo, H.-J. Kim, K. Bai, and J.-K. Park, "The effects of high-power microwaves on the ultrastructure of Bacillus subtilis," Letters in Applied Microbiology, vol. 47, no. 1, pp. 35-40, 2008.

[16] R. Das, "Successful sterilization: ensuring safe, microbial-free organic ingredients," Organic Processing, pp. 22-25, 2008. 
[17] A. Danladi, I. Inabo, E. Yakubu, and S. Olonitola, "Contamination of herbal medicinal products marketed in Kaduna metropolis with selected pathogenic bacteria," African Journal of Traditional, Complementary and Alternative Medicines, vol. 6, no. 1, pp. 70-77, 2009.

[18] F. Khattak, "Microbiological quality assessment of commercially available medicinal plants in Peshawar city, Pakistan," Pakistan Journal of Botany, vol. 44, no. 4, pp. 1203-1208, 2012.

[19] H. Mahanom, A. Azizah, and M. Dzulkifly, "Effect of different drying methods on concentrations of several phytochemicals in herbal preparation of 8 medicinal plants leaves," Malaysian journal of nutrition, vol. 5, no. 1, pp. 47-54, 1999.

[20] S. Roshanak, M. Rahimmalek, and S. A. H. Goli, "Evaluation of seven different drying treatments in respect to total flavonoid, phenolic, vitamin C content, chlorophyll, antioxidant activity and color of green tea (Camellia sinensis or C. assamica) leaves," Journal of Food Science and Technology, vol. 53, no. 1, pp. 721-729, 2016.

[21] P. Manzano Santana, M. Quijano-Avilés, I. Chóez-Guaranda et al., "Effect of drying methods on physical and chemical properties of Ilex guayusa leaves," Revista Facultad Nacional de Agronomía Medellín, vol. 71, no. 3, pp. 8617-8622, 2018.

[22] The British Pharmacopoeia Commission, British Pharmacopoeia (BP), The British Pharmacopoeia Commission, London, UK, 2021.

[23] A. G. Houngbeme, C. Gandonou, B. Yehouenou et al., "Phytochemical analysis, toxicity and antibacterial activity of Benin medicinal plants extracts used in the treatment of sexually transmitted infections associated with HIV/AIDS," International Journal of Pharmaceutical Sciences and Research, vol. 5, no. 5, pp. 1739-1745, 2014.

[24] The International pharmacopoeia, Quality Specification for Pharmaceutical Substances and Dosage Forms Together with Supporting General Methods for Analysis, World Health Organization, Geneva, Switzerland, eight edition, 2018.

[25] World Health Organization, Quality Control Methods for Medicinal Plants Materials, World Health Organization, Geneva, Switzerland, 1998.

[26] S. K. Chandini, L. Jaganmohan Rao, and R. Subramanian, "Influence of extraction conditions on polyphenols content and cream constituents in black tea extracts," International Journal of Food Science and Technology, vol. 46, no. 4, pp. 879-886, 2011.

[27] U. Yuto, A. Nippitch, T. Shuhei, M. Yasushi, A. Varipat, and Y. Shin, "Optimization of hot-water extraction of dried yacon herbal tea leaves: enhanced antioxidant activities and total phenolic content by response surface methodology," Food Science and Technology Research, vol. 25, no. 1, pp. 131-139, 2019.

[28] D. C. Gandonou, H. Ahissou, J.-M. Tokoudagba, and C. Dansou, "Ethnobotanical, phytochemical and toxicity analysis of a Beninese antihypertensive plant: Lippia multiflora," International Journal of Brain and Cognitive Sciences, vol. 11, no. 4, pp. 1816-1828, 2017.

[29] H. W. Djengue, A. Dansi, M. F. Assogba et al., "Phytochemical screening and toxicity of Lippia multiflora Moldenke, a minor aromatic leafy vegetable consumed in Benin, nt," International Journal of Current Research in Biosciences and Plant Biology, vol. 4, no. 5, pp. 77-84, 2017.

[30] J. P. Mevy, J. M. Bessiere, M. Dherbomez, J. Millogo, and J. Viano, "Chemical composition and some biological activities of the volatile oils of a chemotype of Lippia chevalieri Moldenke," Food Chemistry, vol. 101, no. 2, pp. 682-685, 2007.
[31] V. Alexis, P. Yves, B. Francoise et al., "Composition and antimalarial activity in vitro of volatile components of Lippia multiflora," Phytochemistry, vol. 40, no. 5, pp. 1439-1442, 1995.

[32] M. A. Botelho, N. A. P. Nogueira, G. M. Bastos et al., “Antimicrobial activity of the essential oil from Lippia sidoides, carvacrol and thymol against oral pathogens," Brazilian Journal of Medical and Biological Research, vol. 40, no. 3, pp. 349-356, 2007.

[33] A. A. Jigam, H. O. Akanya, E. O. Ogbadoyi, B. E. N. Dauda, and C. E. Egwim, "In vivo antiplasmodial, analgesic and antiinflammatory activities of the leaf extract of Lippia multiflora mold," Journal of Medicinal Plants Research, vol. 3, no. 3, pp. 148-154, 2009.

[34] P. R. Venskutonis, "Effect of drying on the volatile constituents of thyme (Thymus vulgaris L.) and sage (Salvia officinalis L.)," Food Chemistry, vol. 59, no. 2, pp. 219-227, 1997.

[35] L. L. Radünz, E. C. Melo, M. C. Machado, R. R. Santos, and R. H. S. Santos, "Thin layer drying of leaves of Lippia sidoides Cham," in Brazilian Congress of Agric.Eng. Proc., Foz do Iguacu, CONBEA, CD-ROM, 2001.

[36] L. L. Radünz, E. C. Melo, P. A. Berbert et al., "Effects of drying air temperature on the quality of essential oil of rosemary, peppermint (Lippia sidoides Cham.)," Journal of Storage Viçosa, vol. 27, no. 2, pp. 9-13, 2002.

[37] F. d. F. Barbosa, L. C. A. Barbosa, E. C. Melo, F. M. Botelho, and R. H. S. Santos, "Influência da temperatura do ar de secagem sobre o teor e a composição química do óleo essencial de Lippia alba (Mill) N. E. Brown," Química Nova, vol. 29, no. 6, pp. 1221-1225, 2006.

[38] H. Baydar and S. Erbaş, "Effects of harvest time and drying on essential oil properties in lavandin (lavandula $\times$ intermedia emeric ex loisel.)," Acta Horticulturae, vol. 826, no. 826, pp. 377-382, 2009.

[39] I. H. Sellami, W. A. Wannes, I. Bettaieb et al., "Qualitative and quantitative changes in the essential oil of Laurus nobilis L. leaves as affected by different drying methods," Food Chemistry, vol. 126, no. 2, pp. 691-697, 2011.

[40] H. Chandel, A. Pathak, and M. Tailang, "Standardization of some herbal antidiabetic drugs in polyherbal formulation," Pharmacognosy Research, vol. 3, no. 1, pp. 49-56, 2011.

[41] O. A. Ayobami and S. Chibueze Izah, " $\mathrm{pH}$ variation, mineral composition and selected trace metal concentration in some liquid herbal products sold in Nigeria," International Journal of Research Studies in Biosciences (IJRSB), vol. 7, no. 1, pp. 1-8, 2019.

[42] C. T. Onwordi, N. Agbo, and I. A. Ogunwande, "Levels of potentially toxic metals in selected herbal medicines in lagos, Nigeria," Journal of Natural Sciences, vol. 5, no. 2, pp. 148-156, 2015.

[43] R. Odoh and O. E. Ajiboye, "Quality assessment of some selected herbal medicinal products consumed in wukari, taraba state," Acta Scientific Microbiology, vol. 2, no. 9, pp. 28-36, 2019.

[44] N. V. Edebi and O. A. Gideon, "Evaluation of pharmacognostical parameters and heavy metals in some locally manufactured herbal drugs," Journal of Chemical and Pharmaceutical Research, vol. 3, no. 2, pp. 88-97, 2011.

[45] V. Alfred, "Health brand, Body pH-effect of a high acidity level and what you can do," Acta Scientific Microbiology, vol. 2, no. 9, pp. 28-36, 2017.

[46] S. S. Eko, S. E. Indriwati, and E. Suarsini, "Preparation of various type of medicinal plants simplicia as material of Jamu herbal, education in the 21st century: responding to current 
issues," in Proceedings of the International Conference on Education, Hangzhou, China, April 2016.

[47] S. Ahmad, M. N. Amin, and M. Ashik Mosaddik, "Studies on moisture content, biomass yield (crude plant extract) and alkaloid estimation of in-vitro and field grown plant of Rauvolfia sepentina, Pakistan," Journal of Biological Science, vol. 5, no. 4, pp. 416-418, 2001.

[48] C. Wilson, M. Dettenkofer, D. Jonas, and F. D. Daschner, "Pathogen growth in herbal teas used in clinical settings: a possible source of nosocomial infection?" American Journal of Infection Control, vol. 32, no. 2, pp. 117-119, 2004.

[49] R. P. Rocha, E. C. Melo, and L. L. Radünz, "Influence of drying process on the quality of medicinal plants: a review," Journal of Medicinal Plants Research, vol. 5, no. 33, pp. 7076-7084, 2011.

[50] C. M. Bourgeois, J. F. Mescle, J. Zucca, and I. Tome, “Aspect microbiologique de la sécurité alimentaire et de la qualité des aliments," in Microbiologie Alimentaire, T. E. C. Lavoisier, Ed., pp. 106-119, Dunod, Paris, France, 1996.

[51] C. M. Sousa Lima, A. T. F. Mayara, - P. L. Bruno, C. M. Patrícia, F. O.-S. Francisco, and O.-S. Jocivânia, "Microbial contamination in herbal medicines: a serious health hazard to elderly consumers," BMC Complementary Medicine and Therapies, vol. 20, no. 17, pp. 1-9, 2020.

[52] Canadian Food Inspection Agency, Bacterial Pathogens in Dried Herbs and Dried Teas - April 1, 2014 to March 31, 2018, Food Microbiology - Targeted Surveys - Final Report, Canadian Food Inspection Agency, Canada, 2018.

[53] S. Makvana and L. R. Krilov, "Escherichia coli infections," Pediatrics in Review, vol. 36, no. 4, pp. 167-171, 2015.

[54] C. O. Esimone, P. O. Oleghe, E. C. Ibezim, C. O. Okeh, and I. R. Iroha, "Susceptibility-resistance profile of micro-organisms isolated from herbal medicine products sold in Nigeria," African Journal of Biotechnology, vol. 6, no. 24, pp. 2766-2775, 2007.

[55] R. Kulshrestha, C. Gupta, G. Shukla, M. Kundu, S. Bhatnagar, and C. Katiyar, "The effect of water activity and storage temperature on the growth of Aspergillus flavusin medicinal herbs," Planta Medica, vol. 74, no. 10, pp. 1308-1315, 2008.

[56] B. K. Tiwari, V. P. Valdramidis, C. P. O' Donnell, K. Muthukumarappan, P. Bourke, and P. J. Cullen, "Application of natural antimicrobials for food preservation," Journal of Agricultural and Food Chemistry, vol. 57, no. 14, pp. 5987-6000, 2009.

[57] P. S. Negi, "Plant extracts for the control of bacterial growth: efficacy, stability and safety issues for food application," International Journal of Food Microbiology, vol. 156, no. 1, pp. 7-17, 2012.

[58] O. Kunle, J. Okogun, E. Egamana, E. Emojevwe, and M. Shok, "Antimicrobial activity of various extracts and carvacrol from Lippia multiflora leaf extract," Phytomedicine, vol. 10, no. 1, pp. 59-61, 2003.

[59] I. Bassole, A. S. Ouattara, R. Nebie, C. A. T. Ouattara, Z. I. Kabore, and S. A. Traore, "Chemical composition and antibacterial activities of the essential oils of Lippia chevalieri and Lippia multiflora from Burkina Faso," Phytochemistry, vol. 62, no. 2, pp. 209-212, 2003.

[60] A. P. S. Balbani and J. C. Montovani, "Mobile phones: influence on auditory and vestibular systems," Brazilian Journal of Otorhinolaryngology, vol. 74, no. 1, pp. 125-131, 2008.

[61] B. F. Dababneh, "An innovative microwave process for microbial decontamination of spices and herbs," African Journal of Microbiology Research, vol. 7, no. 8, pp. 636-645, 2013.
[62] C. B. A. Yeo, I. A. Watson, D. E. S. Stewart-Tull, and V. H. H. Koh, "Heat transfer analysis of Staphylococcus aureus on stainless steel microwave radiation," Journal of Applied Microbiology, vol. 87, pp. 96-401, 1999.

[63] J. Cañumir, J. Celis, J. Bruijn, and L. Vidal, "Pasteurization of apple juice by using microwaves," Lebensmittel-Wissenschaft und -Technologie, vol. 35, pp. 389-392, 2002.

[64] F. Celandroni, I. Longo, N. Tosoratti et al., "Effect of microwave radiation on Bacillus subtilis spores," Journal of Applied Microbiology, vol. 97, no. 6, pp. 1220-1227, 2004.

[65] M. S. Venkatesh and S. V. Raghavan, "An overview of microwave processing and dielectric properties of agri-food materials," Biosystems Engineering, vol. 88, no. 1, p. 18, 2004.

[66] M. S. Yarmand and A. Homayouni, "Effect of microwave cooking on the microstructure and quality of meat in goat and lamb," Food Chemistry, vol. 112, no. 4, pp. 782-785, 2009.

[67] M. M. Curtis and V. Sperandio, "A complex relationship: the interaction among symbiotic microbes, invading pathogens, and their mammalian host," Mucosal Immunology, vol. 4, no. 2, pp. 133-138, 2011.

[68] G.-A. Lucía, P. Santamaría, R. López et al., "Microwave technology as a new tool to improve microbiological control of oak barrels: a preliminary study," Food Control, vol. 30, no. 2, pp. 536-539, 2012.

[69] M. J. Slobodan, Z. M. Milorad, and L. N. Milan, "The effects of microwave radiation on microbial cultures," Hospital Pharmacology, vol. 1, no. 2, pp. 102-108, 2014.

[70] Y. Shamis, A. Taube, N. Mitik-Dineva, R. Croft, R. J. Crawford, and E. P. Ivanova, "Specific electromagnetic effects of microwave radiation on Escherichia coli," Applied and Environmental Microbiology, vol. 77, no. 9, pp. 30173022, 2011.

[71] I.-S. Woo, I.-K. Rhee, and H.-D. Park, "Differential damage in bacterial cells by microwave radiation on the basis of cell wall structure," Applied and Environmental Microbiology, vol. 66, no. 5, pp. 2243-2247, 2000.

[72] W.-J. Song and D.-H. Kang, "Inactivation of Salmonella Senftenberg, Salmonella Typhimurium and Salmonella Tennessee in peanut butter by $915 \mathrm{MHz}$ microwave heating," Food Microbiology, vol. 53, pp. 48-52, 2016.

[73] R. H. Walters, B. Bhatnagar, S. Tchessalov, K.-I. Izutsu, K. Tsumoto, and S. Ohtake, "Next generation drying technologies for pharmaceutical applications," Journal of Pharmaceutical Sciences, vol. 103, no. 9, pp. 2673-2695, 2014.

[74] C.-H. Chan, R. Yusoff, G.-C. Ngoh, and F. W.-L. Kung, "Microwave-assisted extractions of active ingredients from plants," Journal of Chromatography A, vol. 1218, no. 37, pp. 6213-6225, 2011.

[75] A. Delazar, L. Nahar, S. Hamedeyazdan, and S. D. Sarker, "Microwave-assisted extraction in natural products isolation," Methods in Molecular Biology, vol. 864, pp. 89-115, 2012.

[76] A. K. Kokolakis and S. K. Golfinopoulos, "Microwave-assisted techniques (MATs); a quick way to extract a fragrance: a review," Natural Products Communications, vol. 8, pp. 1493-1504, 2013. 